\title{
MUS81 Gene
}

National Cancer Institute

\section{Source}

National Cancer Institute. MUS81 Gene. NCI Thesaurus. Code C116615.

This gene plays a role in the metabolism of branched DNA structures. 